\title{
(-⿶凵⿴囗十)
}

Citation:

Lashua, BD (2014) DWYL? YOLO. Annals of Leisure Research, 17 (2). 121 - 126. ISSN 1174-5398

DOI: https://doi.org/10.1080/11745398.2014.920761

Link to Leeds Beckett Repository record:

https://eprints.leedsbeckett.ac.uk/id/eprint/31/

Document Version:

Article (Accepted Version)

The aim of the Leeds Beckett Repository is to provide open access to our research, as required by funder policies and permitted by publishers and copyright law.

The Leeds Beckett repository holds a wide range of publications, each of which has been checked for copyright and the relevant embargo period has been applied by the Research Services team.

We operate on a standard take-down policy. If you are the author or publisher of an output and you would like it removed from the repository, please contact us and we will investigate on a case-by-case basis.

Each thesis in the repository has been cleared where necessary by the author for third party copyright. If you would like a thesis to be removed from the repository or believe there is an issue with copyright, please contact us on openaccess@leedsbeckett.ac.uk and we will investigate on a case-by-case basis. 


\section{DWYL? YOLO...}

Brett D. Lashua, Leeds Metropolitan University

The seemingly garbled letters in my title are acronyms for "Do What You Love" (DWYL) and "You Only Live Once" (YOLO), phrases that rest, uneasily, at the heart of this essay. As DWYL and YOLO have become increasingly popular (e.g., in social media networks) these buzzwords have also become indicators of the changing worlds of work and leisure. My central focus on DWYL in this commentary was largely inspired by, and is in part a response to Miya Tokumitsu's (2014) essay “In the name of love." Like Tokumitsu, I take aim at the shifting characteristics of work and concomitant shifts in leisure - both are becoming (worryingly) more alike one another in neoliberal times: increasingly individualized, privatized, commercialized and driven by unfettered market capitalism. What are the wider consequences, for those (especially students) who embrace DWYL, if work becomes more like leisure - or perhaps more dangerously - leisure becomes more like work? The first part of my commentary offers a brief summary of Tokumitsu's essay; then I make links to questions of recreation and leisure studies in higher education, especially questioning the seductiveness of DWYL when it goes hand-in-hand with another buzzword: 'employability'. At a time when many view leisure studies, along with the arts, humanities and social sciences as under threat, DWYL raises serious concerns about the value and role of higher education.

\section{"In the name of love"}

First published in the Jacobin (2014), and then republished in Slate (2014), Tokumitsu observed that in the DWYL era, "labor is not something one does for compensation but is an act of love." Naively, the ethos of DWYL might be interpreted to mean that work which feels like non-work is akin to leisure. This ethos is, at least on its 
glossy surface, splendidly captured in the clichéd line "if you love your job you'll never have to work a day in your life." While, at face value, DWYL would seem a positive idea, often repeated by inspirational figures from Steve Jobs to Oprah Winfrey, Tokumitsu argues that DWYL is a deeply flawed concept. One problem with the DWYL mantra is that its focus is far too narrowly placed on individuals (i.e., do what "you" love). Individuals in new creative economies or leisure industries may very well love what they do, but these fortunate few, in looking at global labour and the creative class (Florida 2002), remain highly elite. As Tokumitsu caustically notes, it is a perhaps a great (loveable) job to create social media via smart phones; it is much less a great job to make those phones. DWYL is blind to 'other' kinds of labour; it epitomizes the individualism inherent in neoliberalism.

A second concern for Tokumitsu, much-related to its inherent individualism and lack of collectivity, is that DWYL "leads not to salvation but to the devaluation of actual work." Rather than risk reproducing a work/leisure dichotomy, Tokumitsu's criticism shows how closely they are now interlaced. The devaluation happens, she argues, because DWYL infers that people are happy to work for lower wages and/or increased hours. In less extreme cases (e.g., as an academic I am fairly happy to work any and/or many odd hours of the day) this is part of how I must navigate and 'succeed' in my work. At its most exploitative, the adjunct professor and unpaid intern are prime examples of DWYL's ill effects; these are but some of the "people persuaded to work for cheap or free, or even for a net loss of wealth" (Tokumitsu 2014, para. 29). Unsurprisingly, 'work' that falls within the creative and cultural enterprises is also widely characterised by "employees willing to work for social currency instead of actual wages, all in the name of love" (Tokumitsu 2014, para. 30). DWYL exemplifies the socioeconomic inequities of neoliberalism.

The disquieting trendiness of DWYL crystallised for me in a recent feature on social media 'news' website Buzzfeed (2013) titled "12 Jobs You Won’t Believe Actually Exist” - 
a piece sponsored, incidentally, by Microsoft Windows. The feature's sub-headline stated: "Do what you love. Love what you do. Do something weird. That's fine too. According to Windows, there's no reason work and play need to be mutually exclusive" - so long as you don't wish to be equitably paid for it? The list spans supposed DWYL employment opportunities from (\#12) a poorly paid post as "the world's fanciest dishwasher" (at Buckingham palace), to toilet tester (\#2) and luxury bed tester (\#1); also making the list were such glamorous gigs as pork rind expert (\#4), and vomit collector (\#10), which sit alongside waterslide tester (\#5) and island caretaker (\#3), among others. Although ridiculous and insidious - meant to generate traffic to a promotional video for the new Windows 'Surface' tablet - these positions are, on the whole, classist (washing dishes for royalty?), insecure, lowly paid, short term, and (as the 'weird' in the sub-headline intimates) extraordinarily isolated.

The isolation illustrated by this list again highlights problems with the neoliberal logic of DWYL (and its carpe diem twin, YOLO) in the ways the maxim embraces individuality and eschews larger social structures and inequitable relations, such as class, gender, and 'race'. As Tokumitsu (2014, para. 14) also pointed out:

One consequence of this isolation is the division that DWYL creates among workers, largely along class lines. Work becomes divided into two opposing classes: that which is lovable (creative, intellectual, socially prestigious) and that which is not (repetitive, unintellectual, undistinguished). Those in the lovable-work camp are vastly more privileged in terms of wealth, social status, education, society's racial biases, and political clout, while comprising a small minority of the workforce.

Yet, and by the same token, just as DWYL privileges a select social class of workers (who might be seen as a new creative class), it additionally privileges a more elite class who benefit most from others' work: 
Do what you love and you'll never work a day in your life! Before succumbing to the intoxicating warmth of that promise, it's critical to ask, "Who, exactly, benefits from making work feel like nonwork?" "Why should workers feel as if they aren’t working when they are?" In masking the very exploitative mechanisms of labor that it fuels, DWYL is, in fact, the most perfect ideological tool of capitalism. If we acknowledged all of our work as work, we could set appropriate limits for it, demanding fair compensation and humane schedules that allow for family and leisure time. (Tokumitsu, 2014, para. 32)

Here, the term 'false consciousness' springs to mind in parallel with Tokumitsu's line of critical questions. Numerous theorists - from Dewey and Freire to Marx and Gramsci (see Dimitriadis and Kamberelis 2006) - have argued that education is crucial to questioning and changing the construction of 'reality', to peek through the ideological masking and concealment (e.g., of capitalism) and strive towards empowerment and political action. Writing in The Guardian (UK) newspaper, Penny (2014, para. 10) mourned the current value of higher education yet maintained, in her advice to students (and presumably their parents) that the ideal value of an education is "not because it'll get them a good job, but because reading, learning and expanding your horizons is necessary if you're going to understand what's being done to the world around you, and change your collective circumstances."

\section{In the name of higher education}

And so, I come finally to the role of higher education in fostering critical views of leisure. The complicity of the university in supporting neoliberal discourses of “managerialism" has come increasingly under fire (Giroux 2012, 2013a, 2013b; Spracklen 2014 in press). Giroux argued that the contemporary university has risked being reduced to "a marketing machine essential to the production of identities in which the only obligation of citizenship is to be a consumer" $(2012,246)$. Others have been even more downcast, 
Published online, Annals of Leisure Research, 27 May 2014, DOI:

http://dx.doi.org/10.1080/11745398.2014.920761

lamenting the purpose of a university degree that has been reduced to becoming

'employable': "fashioning yourself into a walking CV to compete for a stagnant pool of

graduate jobs that are paid less in real terms every year, and taking on a rotten amount of debt in the process" (Penny 2014, para. 4). But who cares if you get to do what you love?

Leisure studies is paradoxically positioned within these debates - many of the careers the field has championed can be seen as 'doing what you love' (often equitably so); however, it is increasingly the case that a degree in critical leisure studies does not appear as a viable path toward employability. There has been a marked recent decline in leisure studies courses (Carr 2013). The "Sport, Leisure and Culture" degree at my own institution was recently closed due to low enrolment, and a proposed replacement called "Sport and Leisure Studies" has not yet been approved over concerns for its marketability to students. Would the word "management" in its title (instead of "studies") have improved its marketability? The Association of American Colleges and Universities (see http://www.aacu.org/) and the Campaign for Social Sciences (see http://www.campaignforsocialscience.org.uk) have been trying to convince the public that an education in the arts and social sciences has practical merit in the real world, yet the outward appearance of the degree name still carries much weight.

Against a backdrop of the rise and fall of leisure studies in higher education, Spracklen (2014 in press) optimistically sees a future for leisure studies "challenging students to think critically within otherwise narrowly focussed 'professional' courses." Such views recentre leisure studies despite the proliferation of sub-fields that has slowly cannibalized leisure studies over the years, carving out increasingly specialized areas in the management of sport, tourism, hospitality, events, and entertainment - all of which offer career paths that fall under the DWYL label. For Spracklen (2014 in press) these new degree titles are more attractive to "prospective students, sound better to parents concerned with employability, and 
Published online, Annals of Leisure Research, 27 May 2014, DOI:

http://dx.doi.org/10.1080/11745398.2014.920761

are easier to market by university managers uncomfortable with the criticality of leisure studies.” Within its critical traditions (see Aitchison 2006; Bramham 2006; Rojek 2010; Spracklen 2009), many leisure studies scholars have responded to the neoliberal consumerization of leisure. Yet, academics are increasingly caught up in processes which often go hand in hand with a culture of managerialism that has 'hollowed out' higher education. Too often it is technical and managerial skills that are valued at the expense of critical questioning. This is an unsurprising outcome of degree courses that prioritise a narrower set of 'employability skills' at the expense of broader lines of social, cultural, and historical inquiry. That a university degree should be practical is perhaps without question; however, that it should also be critical of this practicability is perhaps too easily lost. As the arts, humanities and social sciences come increasingly under attack, some have raised alarms: The American Academy of Arts and Sciences argued in a recent report that we live in a world characterised by change, and therefore a world dependent on the humanities and social sciences. 'How,' asked the academy, 'do we understand and manage change if we have no notion of the past? How do we understand ourselves if we have no notion of a society, culture or world different from the one in which we live?' (Lewis 2014, para. 3).

These are great questions for leisure studies scholars to (continue to) address. Indeed, as Tokumitsu would perhaps also argue, one response to the American Academy of Arts and Sciences line of questioning is that we cannot understand ourselves so long as we only seek to be immediately satisfied in doing what we love - DWYL is asocial, apolitical, and ahistorical; it lacks contextualization. As Giroux might put it, DWYL is indicative of an educational experience in "predefined and isolated bits of information" (2012b, 462). This narrow techno-managerial shift is being driven through the strategic direction of public universities across the globe as they attempt to address the problem of graduate 
unemployment rates. In an age of austerity, there appears to be little public appetite for degree programs that fail to lead to jobs after graduation. For Engell and Dangerfield (1998, para. 50) the decline of the arts, humanities and social sciences, and associated rise of specialised management and administration courses in higher education is nothing short of a disaster:

If we segment our education, prizing only what will produce one kind of economic value, we may segment the totality of our experience and trivialize all values. There is no faster way to guarantee the shattering of our societal mosaic than to assume that its higher education should be the sum of a series of separate professional specializations.

According to Giroux (2013b), the power of education is better engaged to prompt questions, challenges and critiques over who has the power to create knowledge. At worst, if left unaddressed, does the rise of the culture of DWYL signify the wider abandonment by leisure studies (a version of leisure studies that spans arts, humanities and social sciences) in the critical production of public knowledge?

\section{In the name of leisure}

By way of a brief conclusion to tie together (loosely) the threads I have started to unravel above, in the age of DWYL, social inequalities and differences matter little, so long as individual, happy (productive) workers love what they do. Within wider neoliberal frameworks, DWYL signifies the increasing effect(iveness) and apparent 'success' of free market capitalism. As such, DWYL also signals shifts in the "leisure project" that for at least the latter half of the $20^{\text {th }}$ Century anticipated the dawn of the progressive "leisure society" when leisure might be more highly-valued than work (Bramham 2006; Gilchrist and Wheaton 2008). Tokumitsu's (2014) criticism of DWWYL highlights competing and fading visions of this ideal, warning of another nail in its coffin, and in some ways attempting to resuscitate it. 
Although some scholars have argued against the longer term and broader social effects of neoliberalism (see Harvey, 2005), shifts in higher education are part and parcel of this tide, and within it, the currents and currency of employability lead directly to DWYL. While I certainly hope that the students I have worked with have found meaningful and perhaps even lovable employment, I also hope that they do so with a critical eye towards the conditions into which they step into employment. If someone's heart is set upon becoming a 'luxury bed tester', I would hope that they consider the fuller social, historical, political and cultural concerns with which they are getting into bed. If I can admit that I read websites such as Buzzfeed because they are at the cutting edge of recent trends, it is often because they show these trends in the worst possible ways. As such, I'm grateful for the critical education in leisure studies that has encouraged me to continue to question and reconsider practices such as DWYL. Then again, maybe I would love being a professional waterslide tester instead of worrying about the critical importance of leisure; after all, YOLO.

\section{Acknowledgements}

I am grateful to Troy Glover, Neil Carr, Karl Spracklen, and Stephen Wagg for critical conversations and suggestions on various drafts of this commentary.

\section{References}

Aitchison, C. 2006. "The critical and the cultural: explaining the divergent paths of leisure studies and tourism studies." Leisure Studies 25(4): 417-422.

Bramham, P. 2006. "Hard and disappearing work: Making sense of the leisure project." Leisure Studies 25(4): 379-390.

Buzzfeed. 2013. “12 jobs you won’t believe actually exist.” Accessed 9 April 2014. http://www.buzzfeed.com/windowsuk/12-jobs-you-wont-believe-actually-exist. 
Published online, Annals of Leisure Research, 27 May 2014, DOI:

http://dx.doi.org/10.1080/11745398.2014.920761

Dimitriadis, G., and Kamberelis, G. 2006. Theory for Education. New York: Routledge.

Engell, J., and Dangerfield, A. 1998. "The Market-Model University: Humanities in the Age of Money." Harvard Magazine, 111: 48-55. Accessed 9 April 2014.

http://harvardmagazine.com/1998/05/forum.html.

Florida, R. 2002. The Rise of the Creative Class: And How it's Transforming Work, Leisure, Community and Everyday Life. New York: Basic Books.

Gilchrist, P., and Wheaton, B. Eds. 2008. Whatever Happened to the Leisure Society?

Theory, Debate and Policy. Eastbourne: Leisure Studies Association.

Giroux, H. A. 2013a. "Occupy colleges now: Students as the new public intellectuals." Cultural Studies $\leftrightarrow \rightarrow$ Critical Methodologies 13(3): 150-153.

Giroux, H. A. 2013b. "Neoliberalism's war against teachers in dark times.” Cultural Studies $\leftrightarrow$ Critical Methodologies 13(6): 458-468.

Giroux, H. A. 2012. "Why faculty should join Occupy Movement protesters on college campuses." In Qualitative Inquiry and the Politics of Advocacy edited by N. K. Denzin and M. D. Giardina, 245-252. Walnut Creek, CA: Left Coast Press.

Harvey, D. 2005. A Brief History of Neoliberalism. New York: Oxford University Press.

Lewis, E. 2014. "Funding the humanities: what story do we want to tell?" Accessed 9 April 2014. http://www.theguardian.com/higher-education-network/blog/2014/jan/27/funding-artshumanities-university-philanthropy.

Penny, L. 2014. "Sorry students, I lied to you. University is about desperation, not aspiration.” The Guardian [Online]. Accessed 21 April 2014.

http://www.theguardian.com/commentisfree/2014/apr/21/students-i-lied-to-you-desperationgraduate-premium. 
Published online, Annals of Leisure Research, 27 May 2014, DOI:

http://dx.doi.org/10.1080/11745398.2014.920761

Tokumitsu, M. 2014. "In the name of love.” Slate [Online]. Accessed 9 April 2014.

http://www.slate.com/articles/technology/technology/2014/01/do_what_you_love love_what _you_do_an_omnipresent_mantra_that_s_bad_for_work.single.html; originally published in the Jacobin Magazine 13 [Online], accessed 9 April 2014.

https://www.jacobinmag.com/2014/01/in-the-name-of-love/,

Rojek, C. 2010. The Labour of Leisure. London: Sage.

Spracklen, K. 2014 in press. "Leisure studies education: Historical trends and pedagogical futures in the United Kingdom and beyond." Journal of Hospitality, Leisure, Sport and Tourism Education.

Spracklen, K. 2009. The Meaning and Purpose of Leisure: Habermas and Leisure at the End of Modernity. Basingstoke: Palgrave Macmillan. 